\title{
BRAZILIAN KAMAFUGITES
}

\section{PATRICIA BARBOSA DE ALBUQUERQUE SGARB ${ }^{1}$, JOSE CARLOS GASPAR1 ${ }^{2}$ AND JOEL GOMES VALENCA ${ }^{3}$}

\begin{abstract}
Brazilian kamafugites occur in the Mata da Corda (Minas Gerais state) and Santo Antonio da Barra (Goias state) sub-provinces, which belong to Minas-Goias Alkaline Province, one of the Cretaceous alkaline provinces that are located around the Parana Basin in Brazil and Paraguay. The MC and SAB kamafugites are mafurites and ugandites. The rocks are all feldspar-free, with abundant clinopyroxene (mostly diopside) and Ti-magnetite in very fine- to medium-grained porphyritic to seriated textures. Perovskite is abundant in all MC kamafugites but in SAB kamafugites this mineral is accessory or absent. Kalsilite is generally interstitial, often altered. Mineralogically, the ugandites are similar to the mafurites, with the exception that they contain leucite (subhedral pseudomorphs) as the major felsic phase. Also, the mafurites have much more olivine phenocrysts $(5-19 \%$ modal) than the ugandites $(0-3 \%$ modal) while the ugandites have much more feldspathoid. The Brazilian kamafugites here studied are all undersaturated in $\mathrm{SiO}_{2}$ (36.6 to $44.9 \mathrm{wt} \%$ in $\mathrm{MC}$ and 39.9 to $44.2 \mathrm{wt} \%$ in $\mathrm{SAB}$ ), the alkaline characteristic of the rocks being reflected in the contents of $\mathrm{TiO}$ (4.1 to $7.8 \mathrm{wt} \%$ in $\mathrm{MC}$ and 2.8 to $4.1 \mathrm{wt} \%$ in $\mathrm{SAB}$ ), $\mathrm{K} \mathrm{O}$ (1.2 to $6.8 \mathrm{wt} \%$ in $\mathrm{MC}$ and 0.5 to $4.1 \mathrm{wt} . \%$ in $\mathrm{SAB})$, and $\mathrm{Na}_{2} \mathrm{O}(0.49$ to $2.0 \mathrm{wt} \%$ in $\mathrm{MC}$ and 1.0 to $4.3 \mathrm{wt} \%$ in $\mathrm{SAB})$. The presence of normative feldspathoid and olivine and lack of normative quartz are significant. $\mathrm{MgO}$ contents (6.0 to $18.0 \mathrm{wt} \%$ in MC and 5.6 to $15.2 \mathrm{wt} \%$ in SAB) are low when compared to those of other ultrabasic rocks, the highest values being associated with samples of high modal olivine content. The clinopyroxene/magnetite isotopic temperature data of the $\mathrm{MC}$ and SAB kamafugites are in the range of $830-1060^{\circ} \mathrm{C}$ (Sgarbi et al. 1998). The U-Pb perovskite ages of Brazilian kamafugites are in the range of 68-89.6 Ma (Sgarbi et al. 2000).
\end{abstract}

Keywords: kamafugites, mafic alkaline volcanism, Cretaceous, Brasil

INTRODUCTION Kamafugites are kalsilite-bearing volcanics and related rocks (Wooley et al. 1996). They are mafic to ultramafic $\mathrm{SiO}_{2}$ -undersaturated rocks in which the felsic phases are feldspathoids (kalsilite, and/or nepheline and/or leucite). A. Holmes and collaborators $(<$ biblio $>$ ) discovered these rocks in the East African Rift System, along the Southwest Uganda - Zaire border.

The kamafugitic volcanism in Brazil occurs in the Mata da Corda (Minas Gerais state) and Santo Antonio da Barra (Goias state) subprovinces, which belong to Minas-Goias Alkaline Province (Sgarbi \& Caspar, submitted), one of the Cretaceous alkaline provinces that occurs around the Parana Basin in Brazil and Paraguay.

At Mata da Corda (MC), Sgarbi and Valenca (1993) first recognized kamafugites based on the identification of kalsilite in these rocks. The presence of kalsilite in rocks chemically and petrographically similar to the kamafugites from Toro-Ankole, SW Uganda, is an additional evidence of similarities between the rocks of these two volcanic provinces.

The Santo Antonio da Barra (SAB) rocks were first classified as analcimites (Hasui et al. 1971, Caspar 1977, Caspar \& Danni 1979, 1981, Moraes 1984). The finding of leucite and kalsilite for the first time in these rocks (Sgarbi 1998) changed their classification. The presence of relict leucite in some analcime grains confirms the supposition that these analcimites were in fact primary leucitites (Moraes 1988, Danni et al. 1990, Sgarbi et al. 1998). The identification of kalsilite in the SAB lavas (Sgarbi 1998) made it possible to classify them as kamafugites, as other authors expected (Moraes 1988, Danni \& Caspar 1992). This paper presents data on $\mathrm{MC}$ and $\mathrm{SAB}$ kamafugites, emphasizing the similarities and differences between them.

GEOLOGY The Minas-Goias Alkaline Province (Fig. 1) is one of several Cretaceous alkaline igneous provinces that are located around the margin of the Parana sedimentary basin in Brazil and Paraguay. The magmas were emplaced into metamorphic rocks of a narrow Proterozoic mobile belt - the Brasilia Belt - (Fuck et al. 1993, 1994), as well as into the sedimentary rocks of the Parana (Caspar 1977, Moraes 1984) and Sanfranciscan Basins (Sgarbi 1991, Sgarbi \& Valenca 1993).

The Minas-Goias Alkaline Province is composed of ultrapotassic/ potassic, ultrarnafic/mafic, $\mathrm{SiO}_{2}$-undersaturated volcanic and volcaniclastic rocks and pipes (kamafugites, kimberlites, and, after Gibson et al. (1995), possibly madupitic olivine lamproites), besides important plutonic complexes with and without carbonatites.

The MC kamafugites occur in the western part of Minas Gerais State, overlying a non-volcanic sedimentary sequence. The two sequences form the Sanfranciscan Basin of Cretaceous age, and are respectively represented by the Mata da Corda (MC) and Areado Formations. This rock succession is $500 \mathrm{~m}$ thick and unconformably overlies folded metapelites of the Upper Proterozoic Bambui Group.
The MC Formation (Upper Cretaceous) overlies the Areado Formation (Lower Cretaceous), from which is separated by a local erosional unconformity. It comprises a 40 to $60 \mathrm{~m}$ thick pile of kamafugites (Patos fades), volcaniclastic rocks (Capacete facies) and clayey sandstones with little volcanic contribution (Urucuia facies). The lavas outcrop in small exposures (frequently very weathered) of massive and thin horizontal to subhorizontal, poorly vesiculated flows (in places, individually, not exceeding $0.5 \mathrm{~m}$ thick). In some places, the extrapolated thickness of flow sequences may reach up to $10 \mathrm{~m}$ (Sgarbi 1991). Pyroxenites occur as pebbles in the volcanic conglomerate or as cognate xenoliths in the lavas.

The SAB kamafugites occur in the southern part of the Goias State, in a sequence of interbedded lavas and volcaniclastic rocks cut by comagmatic dikes and pipes (Santo Antonio Formation). This sequence is overlain by the Boa Vista Formation, which includes quartz arenites and volcaniclastic sandstones and conglomerates (Verdinho Facies) and limestones interbedded with conglomerates (Ponte Alta Facies). The Boa Vista Formation is part of the Bauru Group, which regionally overlies the Parana basalts and the Botucatu sandstones.

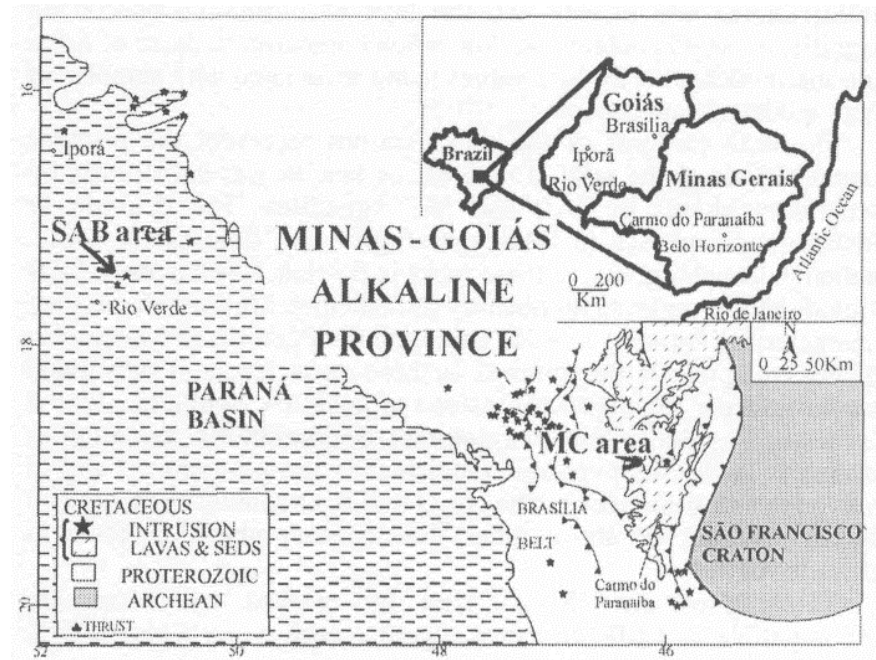

Figure 1 - Location map of MC and SAB areas with major geological features (modified from Gibson et al. 1995)

PETROGRAPHY The MC and SAB kamafugites are mafurites and ugandites. The rocks are all feldspar-free, with abundant clinopyroxene (mostly diopside) and Ti-magnetite in very fine- to medium-grained porphyritic to seriated textures. Perovskite is abundant in all MC kamafugites but in SAB kamafugites this mineral 
is accessory or absent. Interstitial material is always present and is often intensely altered to zeolites and clay minerals. In some MC rocks it has been determined as kalsilite, based on electron microprobe analysis, but in others this material could not be accurately identified and it has been modally considered as an unidentified felsic phase. In SAB kamafugites, nepheline and analcime occur in addition to kalsilite, as interstitial material.

In hand-specimens the mafurites are dark-gray porphyritic aphanites. Under the microscope, they contain phenocrysts (up to 20 vol.\%, and 0.2 to $2.7 \mathrm{~mm}$ in size) of olivine, clinopyroxene (diopside), perovskite (in MC rocks), Ti-magnetite, melilite (euhedral and subhedral pseudomorphs), apatite (apparently absent in SAB rocks) and phlogopite (occasionally up to $3.0 \mathrm{~mm}$ large plates). The very fineto fine-grained groundmass of $\mathrm{MC}$ rocks has clinopyroxene, Timagnetite, and perovskite. Minor amounts of phlogopite and apatite may also be sometimes observed. In hand-specimens, the SAB ugandites present wide textural variation due to the variable amount and distribution of leucite phenocrysts. Macroscopically, MC ugandites are fine-grained phanerites and aphanites. Mineralogically, the ugandites are similar to the mafurites, with the exception that they contain leucite (subhedral pseudomorphs) as the major felsic phase. In SAB ugandites, most leucite pseudomorphs consist of analcime, which also occurs in the interstices of the groundmass. The mafurites have much more olivine phenocrysts $(5-19 \%$ modal $)$ than the ugandites $(0$ $3 \%$ modal) while the ugandites have much more feldspathoid. Scarce and small (mostly $<20 \mathrm{~mm}$ across) cognate xenoliths of pyroxenite may be found as discrete pebbles or included in the MC lavas. These pyroxenites are fine- to medium-grained cumulate rocks, consisting essentially of diopside and containing perovskite, Ti-magnetite, phlogopite, kalsilite and apatite as accessory phases. Rarely, perovskite occurs as the dominant phase in cognate xenoliths, and in this case the rock becomes a perovskitite.

ROCK CHEMISTRY Kamafugites are alkaline ultrabasic volcanic rocks, in general with high contents of $\mathrm{CaO}, \mathrm{FeOt}, \mathrm{TiO}_{2}$, and relatively low $\mathrm{MgO}$.

The Brazilian kamafugites here studied are all $\mathrm{SiO}_{2}$-subsaturated, the alkaline characteristic of the rocks being reflected in the contents of $\mathrm{TiO}_{2}(4.1$ to $7.8 \mathrm{wt} \%$ in $\mathrm{MC}$ and 2.8 to $4.1 \mathrm{wt} \%$ in $\mathrm{SAB}), \mathrm{K}_{2} \mathrm{O}(1.2$ to 6.8 wt. $\%$ in $\mathrm{MC}$ and 0.5 to 4.1 wt. $\%$ in $\mathrm{SAB})$, and $\mathrm{Na}_{2} \mathrm{O}(0.49$ to 2.0 $\mathrm{wt} \%$ in $\mathrm{MC}$ and 1.0 to $4.3 \mathrm{wt} \%$ in $\mathrm{SAB})$. The presence of normative feldspathoids and olivine and the lack of normative quartz are significant. $\mathrm{MgO}$ contents are low when compared to those of other ultrabasic rocks, the highest values being associated with samples of high modal olivine content.

The $\mathrm{K}_{2} \mathrm{O}$ contents of the rocks do not represent the primary compositions of the related magma, as leucite was substituted by secondary phases in SAB and MC ugandites. The deuteric or metassomatic phases in SAB kamafugites are dominantly sodic, although late phlogopite of these rocks is Ba-rich. The leucite in SAB kamafugites is replaced dominantly by analcime. MC kamafugites are characterized by very low $\mathrm{Na}$ contents, the deuteric and alteration phases being mostly Ba-enriched. In these rocks, leucite is substituted by Ba-feldspar (hyalophane) instead of analcime, while kalsilite is substituted by Ba-zeolites (harmotome). Sodium in MC kamafugites occurs in tardi-clinopyroxene (aegirine) in the groundmass and in amygdules of some rocks. The $\mathrm{Na}_{2} \mathrm{O}$ and $\mathrm{K}_{2} \mathrm{O}$ contents of $\mathrm{SAB}$ and $\mathrm{MC}$ kamafugites (see above) reflect the secondary mineralogy found in these rocks.

Kamafugites are characterized by marked enrichment in incompatible and LIL elements together with other typical mafic contents.

In major and minor elements versus $\mathrm{MgO}$ variation diagrams (Fig. 2) mafurites and ugandites form two distinct groups. The MgO contents of mafurites are higher due to the larger amounts of olivine in these rocks. TiO.and $\mathrm{Al}_{2} \mathrm{O}_{3}$ show a negative correlation with $\mathrm{MgO}$, but $\mathrm{FeO}_{\mathrm{t}}$ and $\mathrm{SiO}_{2}$ do not show a clear relation with it. Generally, mafurites are poorer in $\mathrm{Al}_{2} \mathrm{O}_{3}$ and richer in $\mathrm{MgO}$ when compared to ugandites. $\mathrm{SiO}_{2}$ FeOt and $\mathrm{CaO}$ (not shown) contents are similar in both groups and $\mathrm{TiO}_{2}$ in the $\mathrm{MC}$ kamafugites. Regarding these chemical features, a pattern of evolution promoted by fractional crystallization from mafurites toward ugandites is not entirely apparent. However, if the possibility of this evolutionary connection is still considered (see bellow), olivine and clinopyroxene would be likely to be the major fractionated phases.

The minor elements diagrams (Fig.2) show that the concentrations of compatible elements ( $\mathrm{Ni}$ and $\mathrm{Cr}$ ) increase while those of incompatible elements ( $\mathrm{Sr}$ and $\mathrm{Zr}$ ) decrease with $\mathrm{MgO}$, except $\mathrm{Sr}$ in MC kamafugites. These patterns also suggest that fractional crystallization controlled the magma compositions.

MINERAL CHEMISTRY MC (mg \# = 0.85 to 0.91 ) and SAB $(\mathrm{mg} \#=0.83$ to 0.89 ) olivines are similar although $\mathrm{MC}$ ones have a slightly higher range of mg\#. These SAB olivines compare closely to those from Amorinopolis katungite described by Danni \& Caspar (1994).

The typical pyroxene present in kamafugites is diopside. In SAB and $\mathrm{MC}$ kamafugites the pyroxene is dominantly diopside, although in $\mathrm{MC}$ ugandites aegirine-augite may occurs as late phase constituent. Compared to clinopyroxene from MC kamafugites we note that diopside of $\mathrm{SAB}$ kamafugite is richer in $\mathrm{A}_{2} \mathrm{O}_{3}$ (wt.\%). With few exceptions, aluminum occurs in the tetrahedral site. In MC samples some of the green diopside grains are the only pyroxene variety showing ${ }^{\mathrm{VI}} \mathrm{A} 1$. The whole-rock compositions of SAB kamafugites are also richer in $\mathrm{Al}_{2} \mathrm{O}_{3}$ when compared to $\mathrm{MC}$ (Sgarbi \& Caspar 2000, Sgarbi \& Valenja 1995). The titanium contents of most clinopyroxenes from the two subprovinces are in the same range $(0-0.08$ cations per formula). The clinopyroxene in Amorinopolis katungites are Tidiopside characterized by $\mathrm{Si}+\mathrm{Al}$ deficient and $\mathrm{Fe}^{3+}$-rich tetrahedral site. The SiO.contents are always lower than $50 \mathrm{wt} . \%$, differing from those from $\mathrm{MC}$ (SiCL always $>50 \mathrm{wt} . \%$ ) and from most of those from $\mathrm{SAB}$. The Amorinopolis and $\mathrm{SAB}$ pyroxenes have similar $\mathrm{Al}_{2} \mathrm{O}_{3}$ contents.

The mica in SAB and MC kamafugites is always phlogopite with narrow-range of $\mathrm{Al}_{2} \mathrm{O}_{3}$ (9 to $\left.13 w t . \%\right)$. Their $\mathrm{TiO}_{2}$ content ranges between 3 and 8 wt.\%. SAB phlogopite has a high $\mathrm{BaO}$ content (average of $7 \mathrm{wt} . \%$ ), except for that of the olivine pseudomorphs (average of 2 wt.\%). In $\mathrm{MC}$ phlogopite, the $\mathrm{BaO}$ content is lower than $2.5 \mathrm{wt} \%$.

Kalsilite and leucite are the main feldspathoids present in mafurites and ugandites respectively. Kalsilite from MC kamafugites (Sgarbi and Valenea 1993) is richer in $\mathrm{Fe}_{2} \mathrm{O}_{3}(3,6$ to $6,4 \mathrm{wt} \%)$ and has $\mathrm{Na}_{2} \mathrm{O}$ content $(1,1$ to $1,6 \mathrm{wt} \%)$ similar or slightly lower to the SAB kalsilite. MC kalsilite contains significant amount of silica, with $\mathrm{q}$ normative contents averaging $2.7 \%$, well above the $q$ value of $0.9 \%$ found in the SAB kalsilite.

In $\mathrm{SAB}$ and $\mathrm{MC}$ ugandites, leucite is almost totally replaced by secondary minerals. In SAB ugandites, replacement is almost uniquely by analcime. Relicts of unaltered leucite crystals were identified in one of the ugandites studied. Apart from the essential elements, leucite has an average $0,81 \% \mathrm{Fe}_{2} \mathrm{O}_{3}, 0,27 \% \mathrm{BaO}$ and $0,24 \% \mathrm{Na}_{2} \mathrm{O}$. In $\mathrm{MC}$ ugandites leucite pseudomorphs may be anisotropic, resembling pseudoleucite, or isotropic with a turbid, pinkish to brownish appearance. In anisotropic leucite pseudomorphs from $\mathrm{MC}$, hyalophane was identified (Sgarbi 1991). The apparently isotropic pseudomorphs are formed by a very fine aggregate of clay minerals, probably resulting from the alteration of leucite pseudomorphs originally consisting of feldspar or zeolite. In Amorinopolis katungite leucite occurs as clear crystals, with no inclusions and with an almost stoichiometric composition.

The spinels in SAB and MC kamafugites are mainly constituted by ulvospinel and magnetite end members. In SAB mafurites an important presence of chromite end member in spinel phenocrysts is noticed, especially in those that form inclusions in olivine. Spinel in $\mathrm{MC}$ kamafugites has a composition of titanium magnetite with higher content of $\mathrm{Fe}_{2} \mathrm{O}_{3}$ and lower content of $\mathrm{TiO}_{2}$, when compared with the average composition of the $\mathrm{SAB}$ spinel.

The perovskite of the $\mathrm{SAB}$ and $\mathrm{MC}$ kamafugites is compositionally very close to the end-member $\left(\mathrm{CaTiO}_{3}\right)$ with relatively low contents of $\mathrm{REE}$ and $\mathrm{Na}$ and practically no Sr. The SAB perovskite is, however, richer in sodium and has lower contents of REE than the $\mathrm{MC}$ one.

OXYGEN ISOTOPE DATA The clinopyroxene/magnetite isotopic temperature data of $\mathrm{MC}$ and $\mathrm{SAB}$ kamafugites (Sgarbi et al. 1998) are: $\mathrm{MC}$ mafurites $920-1140^{\circ} \mathrm{C}$; MC ugandites $830-920^{\circ} \mathrm{C}$; SAB ugandites $1050-1060^{\circ} \mathrm{C} ; \mathrm{MC}$ pyroxenites $690-750^{\circ} \mathrm{C}$. The lower apparent temperature data obtained for the pyroxenites, which are slower 

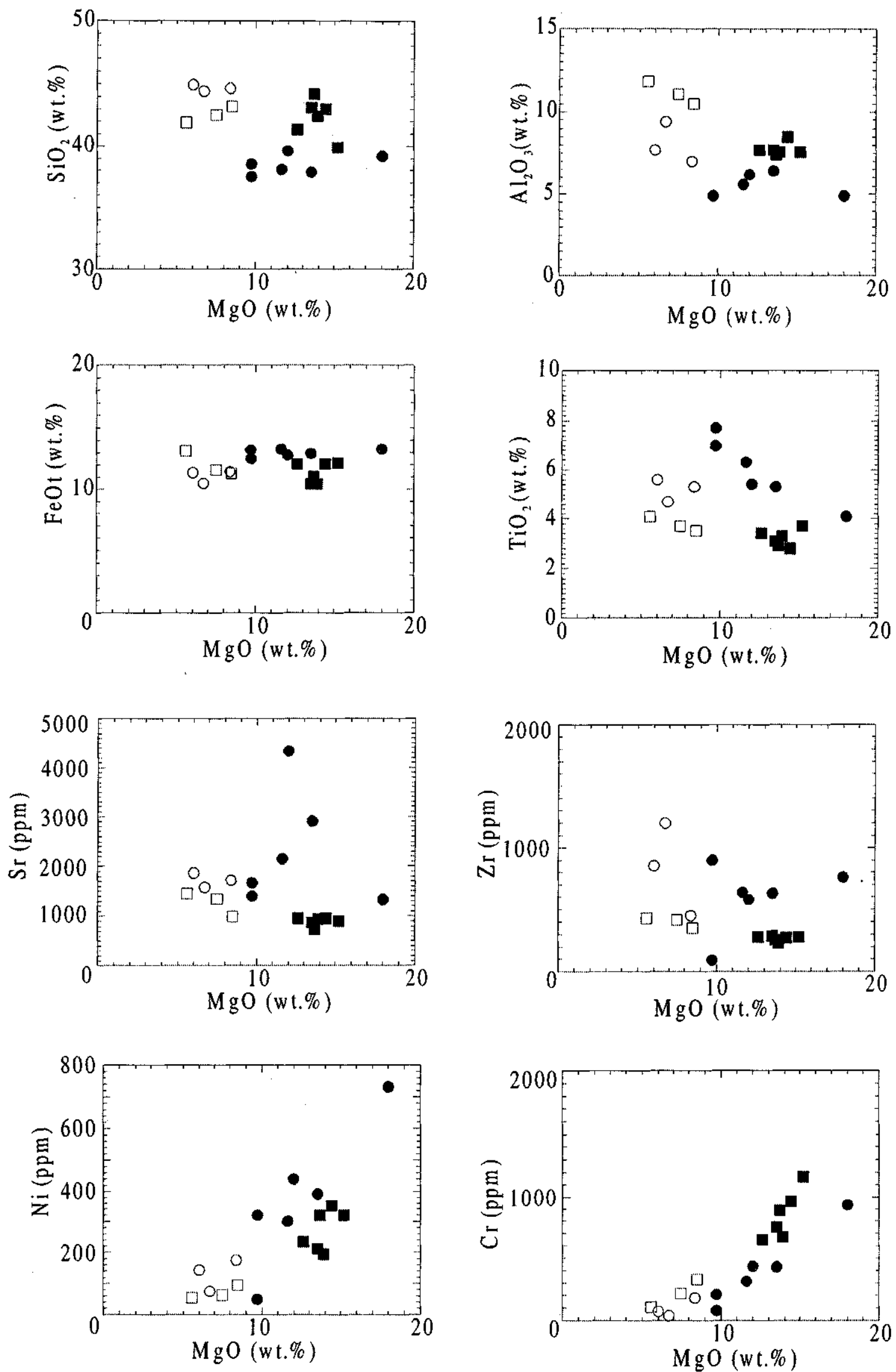

Figure 2 - Major and minor elements versus MoO diagrams for SAB (squares) and MC (circles) kamqfugites. Filled symbols = mafurites; Opens symbols = ugandites. 
cooling subvolcanic rocks, indicate that retrograde exchange was more important in these rocks.

Considering that feldspathoids exchange oxygen very easily (Taylor et al. 1984, Connolly and Muehlenbachs 1988), we used $\delta^{18} \mathrm{O}$ of pyroxene to compare the studied rocks with other mantle-derived rocks, as fractionation between the pyroxene phenocrysts and the melt is small. The range $(5.1$ to $6.3 \% \mathrm{o})$ is lower and partially overlaps the data for the clinopyroxene of other K-rich volcanics 5.9-6.4\%o (Garlick 1966, Kyser et al. 1981, Taylor et al. 1984). The whole rock $\delta^{18} \mathrm{O}$ values obtained in unaltered K-rich potassic rocks are generally higher, $7 \%$ o or greater (Taylor et al. 1984), due to feldspathoid exchange.

The $\delta{ }^{18} \mathrm{O}$ of the pyroxenes from the MC and SAB kamafugites fall in the same range as MORE (Ito et al. 1987). Based on the above considerations, we believe that potassic magmas are not generally $\delta^{18} \mathrm{O}$-enriched compared to MORE.
GEOCHRONOLOGY The U-Pb ages of perovskite (Sgarbi et al 2000) of MC (68-81 Ma) and SAB (88.3-89.6 Ma) show that pulse may be as much as $10 \mathrm{Ma}$. older than the other, indicating an eastward decrease in the age of the ultramafic alkaline magmatism. This progressive decrease in age of magmatism is consistent with proposed hot spot models (Bizzi et al. 1994, Gibson et al. 1995). The determination of precise and accurate emplacement ages of these rocks is important not only to better understand the origin of kamafugites and related rocks in Brazil, but also to understand the temporal relationship between the kamafugitic and tholeiitic magmatism associated with the Trindade or Tristao da Cunha mantle plume.

Acknowledgements To PrPq-UFMG, Fapemig, and CNPq for financial support; CAPES for fellowship to PBAS, and to two anonymous referees of RBG for the critical review of the manuscript.
Combe A.D. \& Holmes A 1945. The kalsilite bearing lavas of Kabirenge and Lyakauli, South West Uganda. Trans. R. Soc. Edinburgh, 61, Pt II, 14, 359.

Connolly C. \& Muehlenbachs K. 1988. Contrasting oxygen diffusion in nepheline, diopside and other silicates and their relevance to isotopic systematics in meteorites. Geochim. Cosmochim. Acta, 52:1585-1591.

Danni J.C.M \& Caspar J.C. 1992. Mineralogia e Quimica de Katungito de Amorinopolis, Goias. In: SBG, Congr. Bras. Geol., 37, Sao Paulo, Resumos Expandidos, 85-86.

Danni J.C.M. \& Caspar J.C. 1994. Quimica do katungito de Amorinopolis, Goias: contribuifao ao estudo do magmatismo kamafugitico. Geochim. Brasil., 8:119-134.

Danni J.C.M., Silva A.J.G.C., Cerqueira M.R. 1990. Petrografia e petroqufmica das rochas alcalinas cretacicas da Serra do Caiapo, SW de Goias. In: SBG, Congr. Bras Geol., 36, Natal, Anais, 4:1872-1882.

Garlick G.D. 1966. Oxygen isotope fractionation in igneous rocks. Earth Planet. Sci. Letters, 1:361-368.

Caspar J.C. 1977. Contribuicdo ao estudo do magmatismo alcalino de Santo Antonio da Barra, GO. IG, UnB, Brasilia, Dissertafao de mestrado, 143 p.

Caspar J.C. \& Danni J.C.M. 197Q Analcima nas rochas vulcanicas de Santo Antonio da Barra, Goias, e suapossiveis implica95es petrogeneticas. Bol. Mineralogico, 6:4149 .

Caspar J.C. \& Danni J.C.M. 1981. Aspectos petrograficos e vulcanologicos da Provincia Alcalina-Carbonatitica de Sto Antonio da Barra, sudoeste de Goias. Rev. Bras. Geociências, 11:74-86.

Gibson S.A., Thompson R.N., Leonardos O.H., Dickin A.P., Mitchell J.G. 1995. The Late Cretaceous impact of the Trindade mantle plume: evidence from large-volume, mafic, potassic magmatism in SE Brazil. J. Petrol., 36:189-229.

Fuck R.A., Jardim de Sa E.F., Pimentel M.M., Dardenne M.A., Scares A.C.P. 1993. As faixas de dobramentos marginais do Craton do Sao Francisco. In Laudim J.M.D.\& Misi A. (eds.) O Craton do Sao Francisco, SBG-SGM-CNPq, Salvador, 161-185.

Fuck R.A., Pimentel M.M., Silva L.J.H.D. 1994. Compartimentacao tectonica da por?ao oriental da Provincia Tocantins. In: SBG, Congr. Bras. Geol., 38 Camboriu, Resumos Expandidos, 215-216.

Hasui Y., Dyer R.C.E., Iwanuch W. 1971. Geocronologia das rochas alcalinas de Santo Antonio da Barra, GO. In: SBG, Congr. Bras. Geol., 25, Sao Paulo, Anais, 253-258.

Holmes A. 1937. The petrology of katungite. Geol. Mag., 74:200-219.

Holmes A. 1942. A suite of volcanic rocks from South West Uganda containing kalsilite (a

polymorph of $\mathrm{KAlSiO}_{4}$ ) Mineral. Mag. 26:197-217.
A. 1945. Leucitized granite xenoliths from potash-rich lavas of Bunyaruguru,SouthWest Uganda. Am.J.Sci. 243:313-333.

Holmes A. 1950. Petrogenesis of katungite and its associates. Am.Miner., 35:772-792.

\section{eferences}

Holmes A. \& Harwood, H.F. 1932. Petrology of the volcanic fields east and southeast of Ruwenzori, Uganda. Q. J. Geol. Soc., 88:370-442.

Ito, E., White.W.M., Gopel, C. 1987. The O, Sr, Nd, and $\mathrm{Pb}$ isotope geochemistry of MORB. Chem. Geol., 62:157-176.

Kyser T.K., O'Neil J.R., Carmichael I.S.E. 1981. Oxygen isotope thermometry of basic lavas and mantle nodules. Contrib. Mineral. Petrol., 77:11-23.

Moraes L.C. 1984. Petrologia, estratigrafia e potencial diamantifero da suite vulcdnica alcalina da regido de Santo Antonio da Barra, Golds. IG, UnB, Brasilia, Disserta930 de Mestrado, $133 \mathrm{p}$

Moraes L.C. 1988. Aspectos petrologicos do magmatismo alcalino cretaceo de Santo Antonio da Barra, Go. Rev. Bras. Geociências, 18:33-42.

Sgarbi P.B.A. 1991. Petrografia e Geoquimica da Formacdo Mata da Corda na regido de Carmo do Paranaiba, MG. UFRJ, Rio de Janeiro, Dissertajao de Mestrado, $214 \mathrm{p}$. sarbi P.B.A. 1998. Mineralogia e petrologia dos kamafugitos da regido de Santo Antonio da Barra sudoeste de Goias. IG UnB, Brasilia, Tese de doutoramento, $226 \mathrm{p}$

Sgarbi P.B.A. \& Valen9a J.G. 1993. Kalsilite in Brazilian kamafugitic rocks. Mineral. Mag., 57:165-171.

Sgarbi P.B.A. \& Valen9a J.G. 1995. Mineral and rock chemistry of the Mata da Corda kamafugitic rocks (MG state, Brazil). International Symposium on the Physics and
Chemistry of the Upper Mantle, Sao Paulo, An. Acad. Bras.CL, 67, .2:257-270.

Sgarbi P.B.A., Clayton R.N., Mayeda T.K., Caspar J.C. 1998. Oxygen isotope thermometry of Brazilian potassic volcanic rocks of kamafugitic affinities. Chemical Geology, of Brazilian potas

Sgarbi P.B.A., Heaman L.M., Caspar J.C. 2000. U-Pb Perovskite ages for Brazilian kamafugites. Submitted to the 31 International Geologic Congress.

Sgarbi P.B.A., Caspar J.C., Valen9a J.G. 2000. Clinopyroxene from Brazilian kamafugites Lithos, in press.

Taylor H.P. Jr., Turi B., Cundari A. $1984 .{ }^{18} \mathrm{O} /{ }^{16} \mathrm{O}$ and chemical relationship in K-rich volcanic rocks from Australia, East Africa, Antarctica, and San Venanzo-Cupaello, Italy. Earth Planet. Sci. Lett., 69:263-276.

Wooley A.R., Bergman S.C., Edgar A.D., Le Bas M.J., Mitchell R.H., Rock N.M.S., Scott Smith B.H. 1996. Classification of Lamprophyres, Lamproites, Kimberlites, and the Kalsilitic, Melilitic, and Leucitic Rocks. Canadian Mineralogist, 34:175-186.

Contribution IGC-145

Received March 1, 2000

Accepted for publication April 28, 2000 